\title{
Mapping Contextual Drivers of HIV Vulnerability: A Qualitative Study of African, Caribbean, Black Youth in Windsor, Canada
}

\author{
Francisca I Omorodion*, Eleanor Maticka-Tyndale and Neema W Jangu \\ Department of Sociology, Anthropology \& Criminology, University of Windsor, 401 Sunset Avenue Windsor ON, Canada \\ ${ }^{\star}$ Corresponding author: Francisca I Omorodion, Department of Sociology, Anthropology \& Criminology, University of Windsor, 401 Sunset Avenue Windsor ON, \\ Canada
}

Received: December 14, 2020; Accepted: December 23, 2020; Published: December 29, 2020

\begin{abstract}
Background: Based on POWER study: Promoting and owning empowerment and resilience among African, Caribbean, and Black Canadian (ACB) youth, this paper explored the contextual factors that expose ACB youth to HIV infection.

Method: We conducted six focused community-mapping sessions with 43 purposively drawn ACB youth living in Windsor, Canada. Based on socioenvironmental approach, we investigated a number of issues including, where to find ACB people, places afraid to go, places to find casual partners, where they spend leisure time, healthy and unhealthy places.

Results: The findings showed that ACB population mainly resides in poor areas, with close proximity to bars, strip shops, recreational/sports places. And, multifaceted factors, such as economic deprivation, marginalization, discrimination, and substance use provided an enabling environment for ACB youth exposure to HIV/AIDS. Conclusion: Future HIV/AIDS prevention must be locality specific and culturally sensitive, by taking into account individual, structural, environmental and socio-cultural factors in future HIV prevention strategies.
\end{abstract}

Keywords: HIVIAIDS, ACB youth, Community mapping, Contextual factors

\section{Introduction}

According to 2018 HIV surveillance report in Canada, Ontario accounted for the highest population of HIV cases (39.2\%), with the second highest reported cases among $20-29$ at $22.5 \%$ Gay, bisexual and men who have sex with men (gbMSM) continue to account for the highest exposure to HIV 58.1\%, while heterosexual transmission accounts for $32.3 \%$, of which $15.4 \%$ are from HIV endemic countries [1]. Similarly in 2017, Ontario accounted for the highest population of new HIV cases (38.9\%), and ACB people infected with HIV through heterosexual contact account for $20 \%$ of the estimated total of all HIVpositive people, and youth aged 15 to 29 accounted for $23 \%$ of HIV cases, and between 2016 to 2017 a $17 \%$ increase in 15 to 19 and $4 \%$ decrease among 20 to 29 [2]. More so, the Black population, which makes up $3.9 \%$ of the population accounts for $22.5 \%$ of persons living with HIV in the province [3]. It also has been estimated that in Ontario, Windsor diagnosis of HIV new cases of 5.7 was fifth, with Toronto having the highest diagnosis rate of 15.7 [4].

Community-based and participatory action research programs on HIV/AIDS risk behaviors have reported that mapping of locations with high concentrations of bars, shops, strip clubs, trucking places, sex workers and other geographical places is crucial in identifying atrisk places, groups, as well as, in designing and implementing effective and sustainable HIV prevention interventions [5]. Community mapping has been used to address development and health issues across multidisciplinary sectors, particularly health issues like infectious diseases [6-8] and HIV/AIDS [9,10]. Other focus of community mapping includes HIV prevention intervention [11,12], and health promotion [13], sex and HIV education [14].

However, mapping as a social research approach has become a growing basis for many interventions in developing countries/ contexts, on development interventions to promote HIV prevention [15-17]. Community mapping is a mixed method approach that involves brainstorming and geographical mapping to visually present ACB youth ideas and perceptions of their vulnerability and resilience to HIV/AIDS. Participants actively participated in ensuring that the maps are explicit, representing and providing adequate knowledge that represents the diverse views of participants.

The present paper explores the factors that expose young $\mathrm{ACB}$ youth to HIV infection in a border city, Windsor, Ontario Canada. It focuses on individual, interpersonal, societal and environmental factors (e.g. access to resources, oppression, discrimination, poverty, and racism) that are often beyond the control of individuals [18-21].

\section{Theoretical Perspectives}

Based on socio-environmental approach, this paper recognizes that individual and collective health are intertwined, such that health 
disparities are the outcomes of intersecting social determinants including neighborhoods, access to economic and social resources, everyday encounters of discrimination and racism, and social exclusion [22]. Integral to this paper are the concepts of masculinity and vulnerabilities. According to UNAIDS [23], people's vulnerability to HIV depends on their personal circumstances, societal factors such as disempowering cultural practices and laws, and the extent to which they have access to appropriate services and supports. However, the UNAIDS definition of HIV vulnerability neglects the role of structural determinants, such as various forms of social oppression, deprivation, and poverty [24]. This paper measures vulnerability in terms of individual attributes such as self-esteem, personal competence, optimism, and related attributes. The focus on individual factors makes invisible those situational and socio-environmental factors (e.g. cultural safety, access to resources, social capital, intergenerational trauma) that are often beyond the control of individuals [21].

\section{Methodology}

\section{Study Community}

Windsor, located in southwestern region of Ontario, and has also been identified as has one the highest rates of immigrants proportional to its population, having the sixth largest concentration of people who have ancestral ties to Africa [25]. According to Statistics Canada (2011) [26], Windsor has the highest proportion (33.3\%) of low-income population living in very low-income neighborhoods. Windsor with the fifth highest HIV diagnosis rate (5.7) among new cases is also a border town with Detroit, Michigan, USA, which has 603 positive sero-status persons per 100,000 people [27]. In addition, its low legal age for alcohol and tobacco consumption, attracts young Americans to visit Windsor bars regularly on weekends and has opened more avenues for social and sexual networking [28]. This networking is likely to create unique local issues. Therefore, it becomes crucial to conduct a study that focuses on Windsor because issues such as youth's and parents' socioeconomic status, inter-country migration or mobility, social hubs, and diversity may nurture cross-border politics and relations.

This study is based on the community mapping of a larger CIHR (2009-2012) funded project on "Promoting and owning empowerment and resilience among African, Caribbean and Black youth in Windsor (POWER)". Engagement process began by organizing a public forum for ACB youth and community based organizations and stakeholders. At the public forum, we developed a list of volunteers to serve in the Youth Advisory Committee (YAC). YAC became a bridge that links the project to the study communities, target population (youth) and promoted participatory involvement of youth at all levels of the research process. We provided a brief overview of the project and particularly the communitybased approach that focus on partnering with the communities and target group as significant actors in the project implementation.

\section{Data Collection}

Two investigators and three staff undertook six focused community mapping group sessions between May and November 2015 with 18-24 years ACB youth living in Windsor. The six group sessions comprised of Youth Advisory Committee (YAC) of university of Windsor students (7), St Claire College (7), Caribbean non-students (7), Black non-students (8) and African non-student (7). Purposive sampling was used to recruit a total of 43 participants. Each group session comprised of homogenous participants in terms of racial/ethnic groups and student status. Two project staff facilitated after being trained over one-week training on community mapping. Each focused group session included seven to eight participants of the same ethno-racial group organizations and student status. Two staff and one investigator facilitated the focused sessions. To begin each session, facilitators introduced the community mapping methodology, including a de-briefing on what the project purpose and goals. Facilitators used a focused semi-structured guide containing prompt questions to lead the discussions, exploring commonalities and differences across the conversation. After each session, the project team debriefed with facilitators, providing additional coaching on issues or ideas that arose during the session. Going around the table, each participant was giving the opportunity to contribute to the discussions. Participants were provided with sticky notes to put down their response if too shy to speak out. Participants had ample uninterrupted time to respond promptly. Participants as a group placed some of their answers on the map of Windsor. Each session lasted between 90 and 120 minutes. The language of communication was English. We took notes and audio taped the discussions. We served snacks and paid participants stipend of $\$ 25$, which included $\$ 5$ for transportation.

\section{Data Analysis}

The staff transcribed the audio recordings verbatim. Two investigators verified the transcripts for accuracy. Project coordinator created the codebook used for coding the transcripts. We used pattern coding by Miles and Huberman (1991) to summarize each transcript. Codes were compiled to record the experiences and perceptions of barriers that tend to expose ACB youth to HIV/AIDS. Staff and two investigators re-examined the coded transcripts for accuracy. And, N6 qualitative software, online coding and data management was used to organize and code the transcripts. The coding process resulted in the identification of the data supporting the emergent themes and the corresponding quotations buttressing the arguments. We made a table of emergent themes, sub-themes and corresponding quotations, which was further reviewed by staff and one investigator for validation. The team overseeing the community mapping read and re-read the themes against the quotations to identify the pattern of arguments.

\section{Results and Discussion}

\section{Background of Participants}

Table 1 shows that participants of African heritage make up the majority (51.2 percent), those of Black heritage were $23.3 \%$, while

Table 1: Participants' Background Characteristics.

\begin{tabular}{|l|c|c|}
\hline Characteristics & Frequency & Percent \\
\hline Race/Ethnicity (N= 43) & No. & \\
\hline African & 22 & 51.2 \\
\hline Black & 10 & 23.3 \\
\hline Caribbean & 9 & 20.9 \\
\hline Mixed & 2 & 4.6 \\
\hline Gender $\mathbf{N = 4 3 )}$ & & \\
\hline Female & 19 & 44.2 \\
\hline Male & 24 & 55.8 \\
\hline
\end{tabular}


Caribbean were $20.9 \%$ and only $4.6 \%$ classified themselves as of mixed heritage. Additionally, in terms of gender, males were $55.8 \%$ and females were $19 \%$. All the sessions were held in a place of close proximity to the participants. For example for university of Windsor and St. Claire College, the sessions were held in the two campuses, while others tended to be held at downtown Windsor.

\section{Places to Find ACB People}

The study probed for the places where ACB people commonly lived. The participants reported that ACB people commonly resided in places where there were affordable housing, with close proximity to social institutions and amenities such as schools, recreations centers. Government provided most of affordable housing tailored to income of tenants. Public maintenance of these housings was timely and at no extra cost to the tenant. More importantly, it was a common practice for newcomers to seek and identify residential places populated by ACB people. Participants identified the west, around sandwich, central and downtown areas as the places to find most ACB people, while they are sparsely located in South Wood Lake area, where the wealthy and affluent ACB families reside. More $\mathrm{ACB}$ people are congregated in the west end/Sandwich, central and downtown, which are crime and poverty-ridden areas. They also noted that a high population of ACB youth, as students, wage earners and those not gainfully employed resided in these areas, either alone or with parents/guardians. Participants also reported a number of social vices such as availability and accessibility to drugs like marijuana, partying, and sex work, which are common around affordable housing places. These social vices expose ACB youth to risk behavior and HIV infection.

In terms of their opinion on living in these places, there were varied ideas. In the Black Canadian mapping session, participants described these areas as: Dirty, lot of prostitutes, Rough area that used to be more violent back in (10), it's a bad area, prostitution, people get robbed beat up all the time (13), it's so retched, ghetto, lots of poverty, No money or jobs are here, A lot of drugs and violence.

\section{The YAC Group Noted That}

There are a lot of young people; a lot of influence, peer pressure, drugs, sports, unprotected sex, good or poor academics, some of the neighborhoods are associated with public housing, immigrant settlement, Glengarry has a waterpark, STAG, community centers, where people can go, --------------, black people are excluded from networking (union)

\section{In the University Students' Session, a Participant Noted}

Relatively impoverished; roads and everything is poorly cared; not much of the city funds go there; a little dangerous; its more affordable; but there is always some type of altercation on my lawn or across the street; I just assumed I would find something more affordable in West Windsor; familiar; they might also feel they can find someone they can relate to (Female Caribbean).

\section{While in the Non-student Group Session, a Participant Added}

Black people are spread out in little areas; West Windsor; bad; but I think it is inclusive, culturally sensitive a good place; unkempt; drugs, boarded houses; not true; there is Windsor housing for immigrants.

\section{Discrimination and Contact with the Police}

Despite the importance of social networking with friends and peers, participants reported that the presence of $\mathrm{ACB}$ youth in predominantly white residential neighborhoods at out-skirts of Windsor, high-end stores, and electronic sections/units of departmental stores, grocery stores and around police stations raises suspicion. Other places identified where teen health center and blood clinic (cited by University group), and prisons (African non-students). The common reasons provided for avoiding these areas are to avoid confrontations with the police, and confrontations involving wrong identity. Participant noted that "If a conflict/confrontation occursautomatically the Black person(s) will be confronted even though the fight was from another race" (African female session). Other youth reported that "violence and crime" are high at downtown Windsor, and ACB youth are often the first suspects.

Participants also reiterated their experiences with the police in a number of places such as residential areas around downtown, west end, university areas; clubs - Boom Boom, house parties; highways and other places such as the mall and stores. Often such encounters with peers and relatives end up as mistaken identity, or it involves highway offense and road checks. A youth noted that with police in Windsor, "they think all Blacks look alike" (African Female, AF). A participant reported that there was a time when a "girl's house was robbed; a dozen police car were present, the last one had a gun pulled out, stopped us for an hour, asked foolish questions, and said you fit the description".

A participant also noted an incident downtown, where ACB boys were hanging out at "McDonalds with white girls, cops harassed us, told us to go home or be arrested for loitering, and promised to call the girl's parents." Police officers would stop an ACB youth and say, "Are you up to something? Are you from Somalia?" (African Male) A student participant also noted: "walking home from university, 20 minutes-walk from home, 2am I was questioned about seeing someone in the area" (AM).

\section{Where do Youth Spend their Free Time?}

In response to the question, "where do youth spend their free time?" participants highlighted a number of places in west of Windsor, such as Sandwich and downtown areas where ACB youth most frequently spend their free time. These places included bars, clubs, strip shops, parks, and sport centers like St. Denis center at the University of Windsor and YMCA, house parties, malls, University library - Leddy and at the theaters. These were common meeting places where they engage in social and sexual networking with each other. Data also showed gender differences as males frequented more places for sports and clubbing, while females tended to patronize places that are less costly, for dancing and were often in company with older siblings and friends. During the walking tours of these areas, the research team and staff were informed that other ACB youth residing in other places in Windsor tended to visit and congregate in these areas to be in company of other peers and friends. We also probed for healthy and unhealthy places in Windsor. The participants reported diverse settings. The 
healthy places ranged from sport places like gyms at YMCA and St. Denis of the University of Windsor; leisure places like STAG, water front located at downtown Windsor; faith-based institutionschurches and mosques, NGO offices like Windsor Women Working With Immigrant Women, Women Entrepreneur Skills Training, New Canadian Center for Excellence, AIDS Committee of Windsor, Youth Connection Association, Salvation Army, and community centers like STAG, Caribbean center. For these youth, these places provided low cost services and were safe and fun places. However, they noted that unhealthy places included parks; downtown area, street allies, and places where many sex workers line the streets, and house parties. The reasons provided ranges from availability of drugs, sexual networking, and exposure to unhealthy behaviors such as sexual activities, drugs and despicable behaviors such as sexing in public places like parks. A participant in identifying what makes these places unhealthy said: Downtown; drugs and alcohol; white women approach Black men; border city; girls from Cincinnati, Pittsburgh, Detroit; 1 in 4 Americans have an STI; Black women give stink eye because it's not healthy (sexually networking with men who have exposed themselves to "risky" White women); strip clubs; studio 4; Teasers; human and drug trafficking; leopards owns 2 houses; keep green cards in safe; European girls; you don't know what they have; police department; racial profiling; west end (street level crime); university of Windsor; break ins and misdemeanours (Caribbean Black Male).

\section{Where to Find Casual Sex Partners}

Participants identified downtown area and facilities -bars, strip clubs, house parties, Studio 4, casino, riverside after hour, massage parlors, parking lots, university library and residences, High school, St Clair, workplaces - factories, street corners - next to Bistro, shops - sex shops (Maxine, Dougall), residential Areas - condos downtown, restaurants - McDonalds (Escorts) as places to find casual sex partners. These places have close proximity to places where ACB people reside provided easy access to "alcohol and casual sexual activity" (African Female, AF). A participant in the University community mapping session said:

You will be surprised at what goes on at this campus. A friend finds a message at Leddy "for a good time call this number" (African Male, AM).

Another participant added, "campus for variety and safety" (African Female, AF)

A participant from the university also said:

AM: bars, strip clubs; university (you would be surprised at what goes on at this campus); speaks about friend who finds a message at Leddy; "for a good time call this number; meet at a house;" (African Male, AM)

Silvers on Seminole, Casino (Caribbean Female, CF).

\section{Secret Places for Secret Things}

To the probe on the secret places where ACB visit and/or congregate to do secret things, not to be heard or known by their parents/guardians, the participants reported bars/s clubs, located in the Sandwich and downtown areas, and specifically university and college campuses where a variety of activities occurred including "alcohol and casual sexual activity" (AF), and youth solicitation for sexual activity. Other activities included drugs, illicit sex, unsafe sex, and prostitution, which are unhealthy and expose persons to STIs including HIV/AIDS. The common reason given for engaging in these activities at these places is that they are "away from home and parents and no need to keep good name".

P4 AF: residence; houses near campus; sell drugs; Askin street near the university; friends of friends; word of mouth

P1 BM: university; residence; college life involves it; alcohol and weed; houses right by campus

P6 CF: apartments on Peter Street; people come in and out at odd hours

P5 ACF: parks; accessible for sex and drugs

P7 AM; coronation school pike park; when house party ends, can go there to be loud or drink

CBM: Riverfront (car sex); hotels on Huron church (strippers from Ottawa, nova scotia); downtown Windsor condos by police station (drugs); Wyandotte and Windermere ( $\mathrm{S}$ and $\mathrm{M}$ club); massage parlours downtown; houses in west end (coke spots); south Windsor (behind Devonshire mall area; cocaine); Banwell (ecstasy).

\section{Discussion}

Community mapping sessions and walking tours provided the researchers and staff a journey into the lived experiences and observations of ACB youth in Windsor, Ontario. The common thread in these accounts and activities was the social inequality, which was more along racial lines that tended to create social exclusion, perpetuating feelings of discrimination and overt racism, which have been reported to have serious impact on ACB communities particularly youth $[18,19,29,30]$ and their attitude to the police [31]. Although these experiences results in lack of entitlement and privilege, thus threatening the social existential survival of ACB population, particularly youth, the community mapping strategies, gave back to these youth some elements of power not just as research participants but also as researchers in the front drive of data collection, informing and making contributions to all stages in the project.

The findings that neighborhoods' context and organization promote ACB youth vulnerability to HIV infection has been buttressed by similar findings from existing studies from the United States and Canada depicting the influence of neighborhood environment and social disorder $[19,20,32]$ neighborhood economic disadvantage [3335] on HIV exposure.

The study also reported that the proliferation of some neighborhoods densely populated by ACB populations with bars, street allies, abandoned houses, availability and accessibility to drugs and alcohol, perpetuate risky behaviors like drug and alcohol use, accessibility and availability of female sex workers. Of significance is the report by participants that there have been rape cases of male and female victims in such neighborhoods due to bad people hiding 
in abandoned properties, and coercing or luring young persons and children into such places. Similarly, a few studies [36-38] suggest that physical environment influences sexual risk and HIV vulnerability. For instance [36], study notes that characteristics of the urban environment influence a wide variety of health behaviors and disease outcomes. They contend that the physical, social and cultural characteristics of urban environment have tolerant social policies through which behaviors and identities may be enacted with less fear. Also noted that inadequately housed individuals tend to be socially isolated or involved in networks that support risky behaviors such as drug use, unstable intimate relationships, multiple sex partners, casual sex exchange and low rates of marriage [39].

The present study also found that a majority of ACB population resides in affordable housing for low to medium very income people families. According to Statistics Canada (2011) [26], Windsor as a town has the highest proportion of low-income populations living in very low-income neighborhoods. Research evidence also shows that people living in very low-income neighborhoods appear to have higher HIV risk profile than those living in higher income areas [18]. Similarly, studies from North America also bear credence to the findings by its association of poverty from social and economic deprivation with HIV risk behaviors $[39,40]$.

Of great importance are past evidence that local bars in Windsor, which attracts youth across the border due to its lower age for alcohol consumption increases the scope of social and sexual networking among Canadian and American youth [28]. Noting that the HIV prevalence rate is very high across Windsor's border city of Detroit (35 new cases per 100,000 residents), and coupled with the early initiation of sex in youth and the poor attitude to and low use of condoms [27,41] the networking between the two cities is likely to increase the exposure of youth to HIV infection. In addition, participants reported going to hidden places away from parents and homes to use drugs, party and indulge in sexual activity. These findings have been documented in other empirical studies showing that young boys and girls use drugs like marijuana and alcohol, which may affect their decision-making [42], and invariable lead to risky behaviors including anal sex [4346], violence [47-51], unprotected sex [52], and having casual and/or opportunistic sex [53-58].

Finally, low parent-child communication on sex also matters. It has been well documented that there is lack of sex talks in families and particularly between parents and children [59-61]. This gap exposes younger ACB youth to risky sexual behaviors such as low condom use and ability to negotiate sex, which has been reported to have serious sexual and reproductive heath consequences like exposure to sexually transmitted infections including HIV/AIDS. However, existing studies on Caribbean population have shown parents willingness to talk about sex and related issues with children [62]. And, it has been reported that parents talk about sex with children leads to abstinence, postponement of sexual initiation, positive attitude to safe sex practices including condom use, and engagement in monogamous relationships [63-68]. Invariably, parent-child communication about sex better prepares children when faced with the decision to have or not to have sex [69]. On the contrary, other studies however reported that some parents feel talking about sex matters with their children and adolescents will introduce them into sexual activities and therefore, they avoid such conversations [64,70]. Although studies remain inconclusive on the outcomes of parent-child talk about sex matters, parental efficacy to improve effective parent-child communication about sex matters remains important [71-85].

\section{Conclusion}

For decades, many HIV prevention research focused on determining, planning and implementing interventions to address individual-level risk behaviors that expose individuals to HIV infection. This present study indicates the importance in examining the environment, social and cultural impediments influencing risky behaviors. African, Caribbean and Black youth in Windsor, specifically young men face pressure from parents and families on children to conform to the social and cultural gendered expectations that makes you a woman (practicing abstinence) and a real man, like being the provider, economically stable, having multiple sex partners, and engaging in unprotected sex, which invariably are likely to increase exposure to HIV infection. This gives credence to this study that engaged $\mathrm{AB}$ youth as both research participants and as researchers, through membership in the Youth Advisory Committee, and actively engaged in recruiting and participating in community mapping and walking tours. More future research need to adopt a mixed method approach, which includes community and/or concept mapping, and other qualitative methods like focus groups, in-depth interviews, photovoice, and questionnaire to study specific subgroups of ACB population like self-identified heterosexual ACB youth, men and women, on a broader scale, provincially or regionally. So doing, we will then be able to establish the differences and similarities across space, neighborhood, race/ethnic subgroups, religion, class and gender in the general population.

The mapping and construction of factors in the environment, neighborhoods, social and cultural contexts among ACB boys, men, girls and women would gain immensely from further investigations. Such interests may provide broader-based data on perceptions of HIV vulnerability, environment and neighborhood factors, with issues of masculinity, specifically perceptions of black masculinity and sexuality that affect sexual scripts, what having sex means, condom use decision making, opportunistic sex, and perceptions of HIV testing.

Furthermore, the findings from this study can begin to inform HIV prevention strategies among ACB youth on how best to increase HIV prevention services. Such programs will focus efforts on addressing multi-level factors by adopting multidimensional, effective and sustainable interventions, which address individual, social, cultural and environmental risky behaviors, like unsafe sexual practices (having multiple sex partners, lack of effective condom use), while also addressing and implementing policies and interventions to improve the environment, neighborhoods, and socio-cultural factors like perceptions of a real black man that hamper the delivery of HIV services aimed at buttressing the sexual and reproductive health of ACB population, specifically youth. 


\section{Acknowledgements}

Canadian Institutes of Health Research (CIHR) provided the funding. The ACBY team includes Kenny Gbadebo, Youth Connection Association; Eleanor Maticka-Tyndale, University of Windsor; Valerie Pierre-Pierre, African Caribbean Council of HIV in Ontario; Robb Travers, Wilfrid Laurier University; Jelani Kerr, University of Louisville, Louisville, KY. Thanks to the study participants for their contribution. The content is solely the responsibility of the author.

\section{References}

1. Haddad N, Robert A, Weeks A, Popovic N, Siu W, et al. (2019) HIV in CanadaSurveillance Report, 2018. Canadian Communicable Respiratory Diseases 45: 304312. [crossref]

2. Haddad N, Li JS, Totten S, McGuire M (2018) HIV in Canada-surveillance report, 2017. Centre for Communicable Diseases Research (CCDR) 44: 348-356. [crossref]

3. Wilton J, Liu J, Sullivan A, Sider D, Kroch A (2017) New HIV diagnoses in Ontario: Preliminary Update, 2016. Ontario HIV Epidemiology and Surveillance Initiative, Toronto, Ontario, October 2017.

4. OHESI Ontario HIV Epidemiology and Surveillance Initiative 2018. HIV in Ontario by public health unit: Testing, new diagnoses and care cascade. November 2018. Toronto, Canada.

5. Campbell C, Foulis C, Maimane S, Sibiya Z (2005) I have an evil child in my house: Stigma and HIV/AIDS management in a South African Community. American Journal of Public Health 95: 808-815. [crossref]

6. Pigott DM, Golding N, Mylne A, Huang Z, Henry AJ, Weiss DJ, et al. (2015a) Mapping the zoonotic niche of Ebola virus disease in Africa. Transactions of the Royal Society of Tropical Medicine and Hygiene 109: 486-492. [crossref]

7. Pigott DM, Golding N, Mylne A, Huang Z, Weiss DJ, et al (2015b). Mapping the zoonotic niche of Marburg virus disease in Africa. Transactions of the Royal Society of Tropical Medicine and Hygiene 109: 366-378. [crossref]

8. Gagnon M, Guta A (2012) Mapping HIV community viral load: Space, power and the government of bodies. Critical Public Health 22: 471-483. [crossref]

9. Dubois-Arber F, Jeannin A, Spencer B, Gervasoni J, Graz B, et al. (2010) Mapping HIV/STI behavioural surveillance in Europe. BMC Infectious Diseases 10: 290.

10. Manda S, Masenyetse L, Cai B, Meyer R (2015) Mapping HIV prevalence using population and antenatal sentinel-based HIV surveys: a multi-stage approach. Population Health Metrics 13: 1-15.

11. Lorway R, Khan S (2014) Reassembling epidemiology: Mapping, monitoring and making-up people in the context of HIV prevention in India. Social Science of Medicine 112: 51-62. [crossref]

12. Corbie-Smith G, Akers A, Blumenthal C, Council B, M. Wynn, et al. (2010) Intervention mapping as a participatory approach to developing an HIV prevention intervention in rural African American communities. AIDS Education Prevention 22: 184-202. [crossref]

13. Kruger DJ, Lewis Y, Schlemmer E (2010) Mapping a message for faith leaders: encouraging ... Health Promotion Practice 11: 837-844. [crossref]

14. Mpofu E, Mutepfa M, Hallfors D (2012) Mapping structural influences on sex and HIV education in church and secular schools. Evaluation and the Health Professions 35: 346-359. [crossref]

15. Abdul-Quader AS, Collins C (2011) Identification of structural interventions for HIV/AIDS prevention: The concept mapping exercisePublic Health Reports 126: 777788. [crossref]

16. Ridings JW, Powell DM, Johnson JE, Pullie CJ, Jones CM, et al. (2008) Using concept mapping to promote community building:The African American initiative at RoselandJournal of Community Practice 16: 39-63.

17. Ridings JW, Piedra LM, Capeles JC, Rodríguez R, Freire F (2010) Building a Latino youth program: Using concept mapping to identify community-based strategies for successJournal of Social Service Research 37: 34-49.

18. Baidoobonso S, Bauer GR, Speechley KN, Lawson E (2013) HIV risk perception and distribution of HIV risk among African, Caribbean and Other Black people in a
Canadian City: Mixed methods results from the BLACCH study. BMC Public Health 13: 184. [crossref]

19. Kerr J, Maticka E -Tyndale, Bynum S, Mihan R (2017) Sexual networking and partner characteristics among single, African, Caribbean, and black youth in Windsor, Ontario. Archives of Sexual Behaviour 46: 1891-1899. [crossref]

20. Kerr J, Northington T, Sockdjou T, Maticka-Tyndale E (2018) Perceived neighborhood quality and HIV-related stigma among African diasporic youth: Results from African, Caribbean, and Black youth (ACBY) study. Journal of Health Care for the Poor and Underserved 29: 651-653. [crossref]

21. Prince-Embury S, Courville T (2008) Comparison of one-, two-, and three-factor models of personal resiliency using the resiliency scales for children and adolescents. Canadian Journal of School Psychology 23: 11-25.

22. Marmot M, Friel S, Bell R, TAJ Houweling, Taylor S (2008) Closing the gap in a generation: Health equity through action on the social determinants of health. Public Health 372: 1661-1669.

23. Szekeres G (2008) The next 5 years of global HIV/AIDS policy: Critical gaps and strategies for effective responsesAIDS 22: S9-S17. [crossref]

24. Doyal L, Anderson J, Paparini S (2009) 'You are not yourself': Exploring masculinities among heterosexual African men living with HIV in London. Social Science \& Medicine S8: 1901-1907. [crossref]

25. Maticka-Tyndale E, Kerr J, Mihan R, the ACBY Team (2016) A profile of the sexual experiences of African, Caribbean and Black Canadian youth in the context of Canadian youth sexuality. The Canadian Journal of Human Sexuality 25: 41-52.

26. Statistics Canada 2011. Immigration and ethnocultural diversity in Canada: 2011 National household surveyCatalogue number 99-010-X2011001. Accessed June 32015.

27. Michigan State Government (2015) Annual HIV Surveillance Report, Michigan. 2015. Lansing, MI: Michigan Department of Health and Human Services.

28. Omorodion F, Gbadebo K, Ishak P (2007) HIV vulnerability and sexual risk among African youth in Windsor, Canada. Culture, Health \& Sexuality 9: 429-437. [crossref]

29. Bowleg L, Neilands TB, Tabb LP, Burkholder GJ, Malebranche DJ, et al. (2014) Neighborhood context and Black heterosexual men's sexual HIV risk behaviors. AIDS Behaviour 18: 2207-2218. [crossref]

30. Husbands W, Oakes W, Mbulaheni T, Ongoïba F, Pierre-Pierre V, et al. (2017) Resourceful masculinities: Exploring heterosexual Black men's vulnerability to HIV in Ontario, Canada. Ethnicity \& Health 25: 1-17. [crossref]

31. Peirone A, Maticka E -Tyndale, Gbadebo K, Kerr J (2017) The social environment of daily life and perceptions of police and/or court discrimination among African, Caribbean, and Black Youth. Canadian Journal of Criminology and Criminal Justice 59: 346-372.

32. Bowen A, Agboatwalla M, Luby S, Tobery T, Ayers T, et al. (2012) Improvements in child development following a cluster-randomized, controlled trial of intensive hand washing promotion in Karachi, Pakistan. Archives of Pediatrics and Adolescent Medicine 166: 1037-1044

33. Hyndman J, Holman J (2001) Accessibility and spatial distribution of general practice services in an Australian city by level of social disadvantage. Social Science and Medicine 53: 1599-1609. [crossref]

34. Hendryx M, Ahern M, Lovrich N, McCurdy A (2002) Access to healthcare and community social capital. Health Services Research 37: 87-103.

35. Kaukinen C, Fulcher C (2006) Mapping the social demography and location of HIV services across Toronto neighbourhoodsHealth and Social Care in the Community 14: 37-48. [crossref]

36. Frye V, et al. (2006) The urban environment and sexual risk behavior among men who have sex with men. Journal of Urban Health 83: 308-324. [crossref]

37. Marshall BDL (2008) The contextual determinants of sexually transmissible infections among street-involved youth in North America. Culture, Health \& Sexuality 10: 787799. [crossref]

38. Sanders T, Campbell R (2007) Designing out vulnerability, building in respect: violence, safety and sex work policy. British Journal of Sociology 58: 1-19. [crossref]

39. Aidala AA, Lee G, Abramson DM, Messeri P, Siegler A (2007) Housing need, housing assistance and connection to HIV medical care. AIDS and Behaviour 11: S101-S115. [crossref] 
40. Adimora AA, Schoenbach VJ (2002) Contextual factors and the Black-White disparity in heterosexual HIV transmission. Epidemiology 13: 707-712. [crossref]

41. Vincent W, Gordon DM, Campbell C, Ward NL, Albritton T, et al (2016) Adherence to traditionally masculine norms and condom-related beliefs: Emphasis on African American and Hispanic men. Psychology of Men \& Masculinity 17: 42-53. [crossref]

42. Wells BE, Kelly BC, Rendina HJ, Parsons JT (2016) Prescription drug misuse and sexual behavior among young adults. Journal of Sex Research 52: 659-668. [crossref]

43. Jenness SM, Begier EM, Neaigus A, Murrill CS, Wendel T, et al. (2010) Unprotected anal intercourse and sexually transmitted diseases in high-risk heterosexual women. American Journal of Public Health 101: 745-750. [crossref]

44. McBride KR, Fortenberry JD (2010) Heterosexual anal sexuality and anal sexual behaviours: A review. Journal of Sex Research 47: 123-136. [crossref]

45. Baggaley RK, Dimitrov D, Owen BN, Pickles M, Butler AR, et al. (2014) Heterosexual anal intercourse: A neglected risk factor for HIV? American Journal of Reproductive Immunology 69: 95-105. [crossref]

46. Marston C, Lewis R (2014) Anal heterosex among young people and implications for health promotion: A qualitative study in the UK. British Medical Journal 4: 1-7.

47. Callands TA, Sipsma HL, Betancourt TS, Hansen NB (2013) Experiences and acceptance of intimate partner violence: Associations with sexually transmitted infection symptoms and ability to negotiate sexual safety among young Liberian women. Culture, Health \& Sexuality 15: 680-694. [crossref]

48. Casey EA, Quema K, Masters NT, Beadnell B, et al. (2016) Patterns of IPV and sexual behaviour among young heterosexually active men. Journal of Sex Research 53: 239250. [crossref]

49. Levesque S, Rodrique C, Beaulieu-Prevost D, Blais M, Boislard M, et al. (2016) Intimate partner violence, sexual assault, and reproductive health among university women. The Canadian Journal of Human Sexuality 25: 9-20.

50. Moya EM, Chavez-Baray S, Martinez O (2014) Intimate partner violence and sexual health: Voices and images of Latina immigrant survivors in South-western United States. Health Promotion Practice 15: 881-893. [crossref]

51. Stockman JK, Lucea MB, Draughon JE, Sabri B, Andersen JC, et al. (2013) Intimate partner violence and HIV risk factors among African-American and AfricanCaribbean women in clinic-based settings. AIDS Care 25: 472-480. [crossref]

52. Roye CF, Krauss BJ, Silverman PL (2010) Prevalence and correlates of heterosexual anal intercourse among Black and Latina female adolescents Journal of the Association of Nurses in AIDS Care 21: 291-301. [crossref]

53. Barnett JP, Maticka E -Tyndale, HP4RY (2011) The gift of agency: Sexual exchange scripts among Nigerian youth. Journal of Sex Research 48: 349-359. [crossref]

54. Devries KM, Free C (2010) 'I told him not to use condoms': masculinities, femininities and sexual health of Aboriginal Canadian young people. Sociology of Health \& Illness 32: 827-842. [crossref]

55. Homma Y, Saewyc EM, Wong ST, Zumbo BD (2013) Sexual health and risk behaviour among East Asian adolescents in British Columbia. The Canadian Journal of Human Sexuality 22: 13-24. [crossref]

56. Lavee E (2016) Exchanging sex for material resources: Reinforcement of gender and oppressive survival strategy. Women's Studies International Forum 56: 83-91.

57. Norbelius A, Kalina B, Pool B, Whitworth J, Chesters J, et al. (2010) "You still need to give her a token of appreciation": The meaning of the exchange of money in the sexual relationships of out-of-school adolescents in rural southwest Uganda. Journal of Sex Research 47: 490-503. [crossref]

58. Poon C, Smith A, Saewyc E, McCreary Centre Society (2015) Sexual health of youth in BC. Vancouver, BC: McCreary Centre Society.

59. Davis AN, Gahagan JC, George C (2013) Everyone just keeps their eyes closed and their fingers crossed: Sexual health communication among black parents and children in Nova Scotia, Canada. International Journal for Equity in Health 12: 55. [crossref]

60. Izugbara CO, Undie C (2008) Masculinity scripts and the sexual vulnerability of male youth in Malawi. International Journal of Sexual Health 20: 281-294.

61. Kuvalanka KA, Weiner JL, Mahan D (2014) Child, family, and community transformations: Findings from interviews with mothers of transgender girls. Journal of GLBT Family Studies 10: 354-379.
62. Wang B, Stanton B, Deveaux L, X Li, Koci V, et al. (2014) The impact of parent involvement in an effective adolescent risk reduction intervention on sexual risk communication and adolescent outcomes. AIDS Education Prevention 26: 500-520.

63. Blake SM, Simkin L, Ledsky R, Perkins C, Calabrese JM (2001) Effects of a parentchild communications intervention on young adolescents' risk for early onset of sexual intercourse. Family Planning Perspectives 33: 52-61. [crossref]

64. Dilorio C, Kelley M, Hockenberry-Eaton M (1999) Communication about sexual issues: Mothers, fathers, and friends. Journal of Adolescent Health 24: 181-189. [crossref]

65. Ford CA, Pence BW, Miller WC, Resnick MD, Bearinger LH, et al. (2005) Predicting adolescents' longitudinal risk for sexually transmitted infection: Results from the National Longitudinal Study of Adolescent Health. Archives of Pediatric Adolescent Medicine 159: 657-664. [crossref]

66. McNeely C, Shew ML, Beuhring T, Sieving R, Miller BC, RVM Blum (2002) Mothers' influence on the timing of first sex among 14- and 15-year-olds. Journal of Adolescent Health 31: 256-265. [crossref]

67. O'Donnell L, Wilson-Simmons R, Dash K, Jeanbaptiste V, Myint UA, et al. (2007) Saving Sex for Later: developing a parent-child communication intervention to delay sexual initiation among young adolescents. Sex Education 7: 107-125.

68. Zhang L, Li X, Shah IH, Baldwin W, Stanton B (2007) Parent-adolescent sex communication in China. The European Journal of Contraception \& Reproductive Health Care: The Official Journal of the European Society of Contraception 12: 138147. [crossref]

69. Haffner DW, Tartaglione AH (2008) Beyond the big talk: Every parent's guide to raising sexually healthy teens-from middle school to high school and beyond. New York, NY: Newmarket Press.

70. Marcell AV, Ford CA, Pleck JH, Sonenstein FL (2007) Masculine beliefs, parental communication, and male adolescents' health care use. Pediatrics 119: e966-e975. [crossref]

71. Wyckoff SC, Miller KS, Forehand R, Bau JJ, Fastula A, et al. (2008) Patterns of sexuality communication between preadolescents and their mothers and fathers. Journal of Child \& Family Studies 17: 649-662. [crossref]

72. African and Caribbean Council on HIV/AIDS in Ontario (2013) Ontario HIV/AIDS strategy for African, Caribbean and Black communities 2013-2018. Toronto: African and Caribbean Council on HIV/AIDS in Ontario.

73. Adimora AA, Schoenbach VJ, FEA Martinson, Coyne-Beasley T, Doherty I, et al. (2006) Heterosexually transmitted HIV infection among African Americans in North Carolina. Journal of Acquired Immune Deficiency Syndrome 41: 616-623. [crossref]

74. Challacombe L (2016) The epidemiology of HIV in females. Accessed June 29.

75. DiClemente RJ, Wingood GM, Crosby R, Cobb BK, Harrington K, et al. (2001) Parent- adolescent communication and sexual risk behaviours among AfricanAmerican adolescent females. Journal of Pediatrics 139: 407-412. [crossref]

76. Ford K, Wirawan DN, Muliawan P (2002) Social influence, AIDS/STD knowledge, and condom use among male clients of female sex workers in Bali. AIDS Education Prevention 14: 496-504. [crossref]

77. Frisch M (2016) Higher frequency of unprotected insertive anal sex among young Black MSM who are circumcised. AIDS Behavior 20: 2543-2544. [crossref]

78. Hess KL, DiNenno E, Sionean C, Ivy W, Paz-Bailey G (2016) Prevalence and correlates of heterosexual anal intercourse among men and women, 20 U.S. cities. AIDS Behavior 20: 2966-2975. [crossref]

79. Hutchinson MK (2002) The influence of sexual risk communication between parents and daughters on sexual risk behaviour. Family Relations 51: 238-247.

80. Hutchinson MK, Jemmott JB, Jemmott LS, Braverman P, Fong GT (2003) The role of mother-daughter sexual risk communication in reducing sexual risk behaviors among urban adolescent females: A prospective study. Journal of Adolescent Health 33: 98e107. [crossref]

81. Kaul R, Cohen CR, Chege D, Yi TJ, Tharao W, McKinnon LR, et al. 2011. Biological factors that may contribute to regional and racial disparities in HIV prevalence. American Journal Reproductive Immunology 5: 317-324. [crossref] 
Francisca I Omorodion (2020) Mapping Contextual Drivers of HIV Vulnerability: A Qualitative Study of African, Caribbean, Black Youth in Windsor, Canada

82. Miles M, Huberman A (1994) An expanded source book: Qualitative data analysis. (2nd ed). London: Sage.

83. Remis R, Swantee C, Liu J (2012) Report on HIV/AIDS in Ontario 2009. Ontario HIV Epidemiologic Monitoring Unit.
84. Tuckett A (2005) Part II: Rigour in qualitative research- complexities and solutions. Nurse Researcher 13: 29-42. [crossref]

85. Vingilis E, McLeod AI, Seeley J, Mann R, Voas R, et al. (2006) The Impact of Ontario's extended drinking hours on cross-border cities of Windsor and Detroit. Accident Analysis \& Prevention 38: 63-70. [crossref]

Omorodion FI, Maticka-Tyndale E, Jangu NW (2020) Mapping Contextual Drivers of HIV Vulnerability: A Qualitative Study of African, Caribbean, Black Youth in Windsor, Canada. ARCH Women Health Care Volume 3(5): 1-8. 